\title{
Research on the Impact of Corporate Social Responsibility Behavior on Financial Performance from the Perspective of Optimal Differentiation
}

\author{
Jingyu $\mathrm{Fu}^{1}$, Jihong $\mathrm{Wu}^{2, *}$, Guiqing $\mathrm{Li}^{1}$, Yaqing Zhang ${ }^{1}$, Chizhou $\mathrm{Zhu}^{1}$ and Jie $\mathrm{Liu}^{1}$ \\ ${ }^{1}$ School of Management, Chengdu University of Information Technology, Chengdu, Sichuan 610103, China \\ ${ }^{2}$ School of Management and Economics of UESTC, University of Electronic Science and Technology of China, Chengdu, \\ Sichuan 611731, China \\ *Corresponding author.Email: wujh@uestc.edu.cn
}

\begin{abstract}
This paper aims to provide a new social responsibility strategic portfolio for Chinese listed companies. Using the optimal differentiation theory. this paper calculates a new social responsibility index from a multidimensional perspective, and empirically analyses the relationship between social responsibility and financial performance. The conclusions are as follows: (1) the consistency of CSR has an inverted U-shaped relationship with financial performance, and the difference of CSR has a U-shaped relationship with financial performance. (2) Increasing R\&D investment will weaken the inverted U-shaped impact of CSR consistency on financial performance, but increasing $R \& D$ expenses and $R \& D$ personnel investment does not regulate the U-shaped relationship between CSR difference and financial performance. The innovation of this study is to use new social responsibility indicators to demonstrate the impact on corporate financial performance, to provide new ideas for corporate social responsibility strategy.
\end{abstract}

Keywords: Optimal differentiation theory, Corporate social responsibility, $R \& D$ investment, Financial

\section{performance}

\section{INTRODUCTION}

On 17 August 2021, at the tenth meeting of the Central Finance and Economics Commission, the topic of "Promoting common prosperity through high-quality development" was proposed to build a basic institutional arrangement that coordinates the primary distribution, redistribution, and the three distributions. By complementing the third distribution with the first and second distributions, the three distributions will play a joint role in regulating property, which will help the entire population to make more visible and substantial progress towards common prosperity. This shows the urgency of improving and strengthening corporate social responsibility for the country's economic development at this stage, improving the system of charitable fund-raising, charity record statistics, charity recognition, and promoting the normalization and institutionalization of volunteerism to better play the role of the third distribution of corporate social responsibility.

The purpose of empirical CSR research is that firms want to have a positive impact on performance through socially beneficial activities (Rowley, Berman, 2000)[1]. CSR also helps to differentiate itself from its competitors and improves corporate financial performance by building reputation and gaining support from different stakeholders. However, previous studies on the relationship between
CSR and corporate financial performance have found inconsistent findings, and the mechanisms by which CSR promotes financial performance are complex and go beyond direct causation (Clyde Eiríkur Hull, Sandra Rothenberg, 2008)[2]. However, the empirical findings show a small but positive relationship overall, confirming that CSR is strategically sound (Herman Aguinis, 2012)[3]. Increasingly, scholars are now conducting more disaggregated CSR research, focusing on specific types of CSR activities and their indirect effects on corporate performance (Flammer Caroline, 2013)[4]. However, as research has become more segmented and focused, the field as a whole has become more fragmented. Whereas CSR is a multidimensional concept, most of the previous studies were conducted only from a single dimension and the conclusions obtained were somewhat one-sided, so this study combines network analysis to link the various areas of CSR and constructs a multidimensional network matrix for empirical analysis to make the findings more convincing and comprehensive.

Carroll (1979)[5] proposed the most influential pyramid model of CSR: economic, legal, ethical, and voluntary responsibility. It is worth noting that economic and ethical responsibility go hand in hand, and this paper proposes CSR consistency and CSR differentiation in conjunction with optimal differentiation theory (Yanlong Zhang et al., 2017)[6], compared to CSR consistency, which reflects a firm's ethical responsibility, and CSR differentiation, 
which reflects a firm's economic responsibility. Among them, economic responsibility requires that firms must enhance their corporate value by continuously striving to introduce new products, methods, and initiatives, for which this paper explains the complex relationship between CSR and financial performance by introducing corporate $R \& D$ investments.

In summary, this study explores the mechanism of the role of CSR on financial performance from the perspective of optimal differentiation. Based on the social responsibility practices of Chinese listed companies, the impact of CSR with different strategies on financial performance and the moderating role played by $R \& D$ investment are examined empirically. It is found that increasing $R \& D$ investment stabilizes the positive impact of CSR consistency on financial performance but does not play a role in the Ushaped impact of CSR differentiation on financial performance. Based on the perspective of optimal differentiation theory, this paper provides new ideas for listed companies to balance the impact of CSR consistency and differentiation on financial performance, thus contributing to the development of optimal differentiation theory.

\section{THEORETICAL ANALYSIS AND HYPOTHESIS FORMULATION}

\subsection{Relationship between corporate social responsibility and financial performance under the theory of optimal differentiation}

Corporate financial performance, as a corporate governance strategy, is the ultimate expression of corporate strategy and the effectiveness of its implementation, which not only satisfies the needs of stakeholders but also enhances corporate reputation and financial performance. Sean T. Hannah (2020)[7], through a review of published literature, concluded that $59 \%$ of the studies showed a positive impact of CSR on financial performance. On this basis, it has been suggested that the relationship between CSR and financial performance is U-shaped. They argue that it is costly for companies to be socially responsible but at the same time they will gain more stakeholder influence. For firms with less CSR behaviors to undertake, financial performance is high when they invest less in CSR behaviors, but stakeholder influence may not be sufficient to generate benefits that offset the costs, and the CSRfinancial performance relationship is negative in this range, and financial performance gradually decreases. For firms with high CSR behavior commitment, when enough stakeholder influence is accumulated, the CSR-financial performance relationship is positive in this range and therefore can convert socially responsible investments into financial returns. Overall, this means that the curve slopes downward until sufficient stakeholder influence is accumulated; CSR is an investment that provides a negative return. Thereafter, the curve flattens out and for those firms that have accumulated sufficient stakeholder impact, the curve goes up and gets progressively smaller CSR becomes an investment that provides a positive return (Michael L. Barnett, 2012)[8].

In addition, since the fulfillment of social responsibility by enterprises needs to go through the transformation process of information, first gaining more attention from stakeholders, then gaining more resources and investment, and finally transforming into the financial performance of enterprises. It can be seen that the impact of CSR on financial performance has a certain lag, and not considering the lag in the process of empirical analysis will affect the accuracy of the conclusions. And studies by scholars have already concluded that social responsibility with a lag of one period has a significant positive impact on financial performance in the current period (Zhang Zhaoguo et al., 2013)[9]. Based on the above view, this paper proposes the first basic hypothesis :

H1: There is a U-shaped relationship between corporate social responsibility in the current period and financial performance in the later period.

Social psychologist Marilynn Brewer first proposed the theory of optimal differentiation in 1991, which refers to the two contradictory needs of a person to be consistent with others and to highlight his or her uniqueness at the same time, and the core of this theory is "seeking commonality or keeping differences". "Seeking commonality" means that an enterprise will be recognized by society and the state if it satisfies the need for consistency, but at the same time it will be subjected to greater competitive pressure, which will hinder its sustainable development; "Keeping differences" means that an enterprise will obtain its unique technological and competitive advantages if it satisfies the need for differences, but at the same time it may face the problem of social legitimacy. But at the same time, they may face the test of social legitimacy, which makes it difficult to obtain continuous support from stakeholders and thus hinders their access to resources. In response to previous literature, which measured CSR mostly in terms of units or multiple dimensions independent of each other, some scholars have provided a better understanding of stakeholder networks, arguing that stakeholder networks are continuous rather than discrete multiplicity, where value exchange becomes complex rather than just binary; i.e., markets are now networked, with individual firms connected through information and resource exchange (Hillebrand B, 2015)[10]. Therefore, in the future, the impact of a firm's network position (a structural hole, centrality, etc.) in the network established with various stakeholders on the relationship between CSR and financial performance should be considered. On this basis, this paper introduces the theory of optimal differentiation from the perspective of corporate needs and divides CSR behavior into CSR consistent behavior and CSR differentiated behavior using GRI as a criterion. From the nine dimensions of shareholders, creditors, employees, suppliers, customers and consumers, environment and sustainable development, social responsibility system construction and improvement measures and safety production content, the consistency of 
CSR and the differentiation of CSR of each enterprise are calculated separately by network analysis method to explore how it will have an impact on the financial performance of the enterprise.

In summary, this paper argues that CSR consistency in the early stage on CSR behavior invested more costs, at this time the benefits of stakeholder influence can not offset the costs, but with the accumulation of CSR consistency behavior, stakeholder influence is also increasing, and then continuously increase corporate financial performance; but when CSR consistency behavior accumulated to a certain degree, because CSR consistency behavior It is difficult to form unique corporate competitiveness, thus negatively affecting financial performance. CSR's differential behavior in the early CSR behavior to invest less cost, financial performance will be high, but not easy to obtain public recognition, CSR - financial performance relationship in this range is negative, financial performance will gradually reduce; with the accumulation of practice to form a unique competitive advantage of enterprises, strengthen the stakeholder influence, thus positively affecting the financial performance of the enterprise and increasing the value of the enterprise. Based on the above view, this paper proposes the following hypothesis based on the first basic assumption:

H1a: There is an inverted U-shaped relationship between current period consistent CSR behavior and later period corporate financial performance.

$\mathrm{H} 1 \mathrm{~b}$ : Current period differential CSR behavior has a Ushaped relationship with later period corporate financial performance.

\subsection{The moderating role of $R \& D$ investment under optimal differentiation theory}

Since, the expected impact of CSR on financial performance changes over time (Awaysheh Amrou, 2020)[11], it receives many factors in the process. In this regard, some scholars have analyzed four positive factors that influence the relationship between CSR and financial performance through meta-analytic structural equation modeling based on available empirical, evidence: i) improving corporate reputation; ii) increasing stakeholder returns; iii) reducing corporate risk; and iv) enhancing innovation, which together explain $20 \%$ of the relationship between CSR and financial performance (Vishwanathan Pushpika, 2020)[12]. Therefore, this paper explores the positive factor of corporate innovativeness and examines in the empirical evidence how R\&D investment indicators moderate the impact of CSR on financial performance. Since R\&D investment is also characterized by long investment cycle and lag, and it will only contribute to corporate financial performance when it accumulates to a certain extent (Minlian Wu, 2020)[13]. Based on the above view, this paper proposes the second basic hypothesis :

$\mathrm{H} 2$ : Enhanced current R\&D investment moderates the relationship between current CSR and later financial performance.
Long-term consistent CSR behavior can lead to a decline in financial performance due to the failure to develop unique corporate competitiveness, when firms increase their investment in R\&D, attracting stakeholder consumption and investment with the output of new products, new cultures, etc., and thus sustainably improving financial performance. It is found that venture capital can have a positive mechanism of action on the financial performance of enterprises: i) venture capital support can make full use of industry spillover R\&D resources by enabling enterprises; ii) reduce the uncertainty faced by enterprise development; iii) help enterprises to compete effectively in the market, and iv) alleviate the external financing constraints of enterprises. Venture capital can improve the efficiency of a firm's R\&D investment and can enhance its future financial performance to a greater extent ( $\mathrm{Li}$, Monya, and Yan, Taihua, 2020)[14]. Therefore, the differential behavior of firms when they tend to CSR can also be regarded as a kind of risk investment, when increasing R\&D investment can improve the future financial performance of the firm to a greater extent. Based on the above view, this paper proposes the following hypothesis based on the second basic assumption:

H2a: R\&D investment weakens the inverted U-shaped relationship between consistent CSR behavior and corporate financial performance.

H2b: R\&D investment weakens the U-shaped relationship between differential CSR behavior and corporate financial performance.

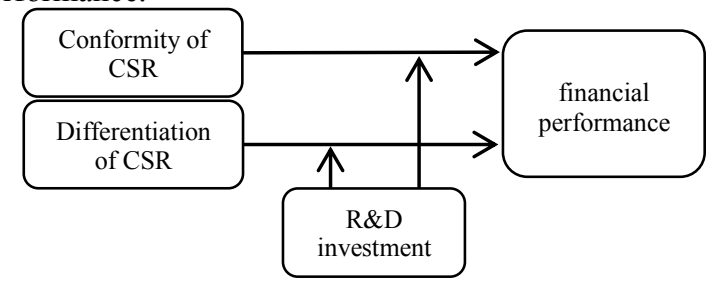

Figure 1. Theoretical model

\section{STUDY DESIGN}

\subsection{Sample selection}

This paper selects listed companies from 2012-2018 as the research sample, and to avoid the impact of special samples on the accuracy of the empirical analysis, screening is performed as follows: (1) exclude ST, *ST, and PT companies; (2) exclude the financial sector; and (3) exclude companies with missing financial data. To eliminate the effect of extreme values on the empirical results, continuous-type variables with outliers were subjected to $1 \%$ quantile tail reduction. The number of CSR content disclosures was obtained from the detailed list of CSR reports of listed companies, and all other data indicators were obtained from the Guotaian CSMAR database. 


\subsection{Description of variables}

\subsubsection{Explanatory variable: Corporate social responsibility}

The GRI international standard has established a standard for the implementation of socially responsible behavior for companies. This study determines the weights of the nine CSR dimensions of the GRI international standard (shareholders, creditors, employees, suppliers, customers, environment and sustainable development, social responsibility system construction and improvement measures, and safety production content) through the conceptual network method. The correlation matrix of each dimension by year was first created using the number of projects implemented in each dimension by disclosing CSR in the social responsibility reports of listed companies, using each of the nine dimensions of CSR as columns and rows. To assess the importance of each dimension, the eigenvector centrality value of each dimension for that year was calculated through the correlation matrix (Yanlong Zhang et al., 2017)[6]. In this paper, CSR is divided into CSR consistency and CSR differentiation.

Conformity of CSR: assesses the conformance of the socially responsible behavior that each company has done to the standard by summing up whether the company fulfilled the social responsibility of the dimension in the current year (yes is 1, no is 0) and the eigenvector centrality score of each dimension in the previous year, and finally the higher the total score indicates the better the company is doing in CSR conformance.

Differentiation of CSR: Assesses the extent to which firms deviate from peer firms in their socially responsible behavior. First, the difference between whether a firm discloses and the industry average is calculated for each dimension, and then the absolute value of the industry difference for each firm in the current year is weighted using the eigenvector centrality values for each dimension in the previous year. The weighted sum of the differences for all nine CSR dimensions is used as an indicator of the difference between CSR and the industry average. The lower the score, the more consistent it is with the practices generally adopted by the industry; the higher the score, the more different the CSR behavior is from the industry average, making the CSR behavior unique compared to other firms.

\subsubsection{Explanatory variable: financial performance}

TobinQ is the ratio of the sum of a company's market capitalization and debt book value to its total assets, a forward-looking indicator that reflects a company's growth potential, profit sustainability, and investors' expectations of the company's future profitability. TobinQ is often used as a financial performance indicator to test the relationship between CSR and financial performance. Therefore, tobinQ is chosen as a measure of corporate financial performance in this paper.

\subsubsection{Moderating variable: $R \& D$ input}

R\&D input includes $R \& D$ expense input and $R \& D$ personnel input. There are two ways to calculate R\&D input, one is the ratio of R\&D input to total assets; the other is the ratio of $R \& D$ input to operating revenue, and this paper uses the ratio of $R \& D$ input to operating revenue. $R \& D$ personnel is the core of human resources in science and technology, and adjusting and expanding the talent team of R\&D personnel can improve the efficiency of R\&D output, therefore, this paper adds the index of R\&D personnel input to the variables of $R \& D$ input to measure.

\subsubsection{Control variables: as in Table 1}

Table 1. Table of variable descriptions

\begin{tabular}{|c|c|c|}
\hline $\begin{array}{c}\text { Variable } \\
\text { Type }\end{array}$ & $\begin{array}{l}\text { Variable } \\
\text { symbol }\end{array}$ & meaning \\
\hline \multirow{2}{*}{$\begin{array}{c}\text { Explanatory } \\
\text { variables }\end{array}$} & conformity & $\sum_{\mathbb{i}=1} \operatorname{CENi}(t-1) \operatorname{CSR} i t$ \\
\hline & differentiation & $\sum_{i=1}|A E i t-F E i t| C E N i(t-1)$ \\
\hline $\begin{array}{l}\text { Explained } \\
\text { variables }\end{array}$ & tobinQ & $\begin{array}{c}\text { Potential future value of } \\
\text { the business }\end{array}$ \\
\hline \multirow{2}{*}{$\begin{array}{l}\text { Regulating } \\
\text { variables }\end{array}$} & research_input & $\begin{array}{c}\text { Amount of } \mathrm{R} \& \mathrm{D} \\
\text { investment / Operating } \\
\text { revenue } * 100 \%\end{array}$ \\
\hline & research_staff & $\begin{array}{c}\text { Number of R\&D staff / } \\
\text { Total number of } \\
\text { employees } * 100 \%\end{array}$ \\
\hline \multirow{3}{*}{$\begin{array}{c}\text { Control } \\
\text { variables }\end{array}$} & Lev & $\begin{array}{c}\text { Total liabilities/total } \\
\text { assets } * 100 \%\end{array}$ \\
\hline & Indiratio & $\begin{array}{l}\text { Percentage of independent } \\
\text { directors }\end{array}$ \\
\hline & Ownership & $\begin{array}{c}1 \text { for state-owned } \\
\text { enterprises, } 0 \text { otherwise }\end{array}$ \\
\hline
\end{tabular}

\section{EMPIRICAL RESULTS AND ANALYSIS}

\subsection{Descriptive statistics}

From the descriptive statistics of the sample, it can be seen that the mean value of the consistency of CSR is 1.743 , with a standard deviation of 0.375 , and the mean value of the difference of CSR in comparison is 0.160 , with a standard deviation of 0.183 , which shows that most enterprises are doing a relatively uniform job in undertaking consistent social responsibility behavior, but have not formed a unique social responsibility strategy of enterprises; the mean value of the financial performance of 
enterprises is 1.9464 , with a standard deviation of 13.13 , indicating that there is still a certain gap between the financial performance of different enterprises; the mean value of $R \& D$ cost investment is 4.009 , with a standard deviation of 4.490 , compared with the mean value of $R \& D$ personnel investment of 10.500 , with a standard deviation of 12.940 , reflecting the differences in the importance of various $\mathrm{R} \& \mathrm{D}$ investments among different companies. Other control variables as shown in Table 2.

Table 2. Descriptive statistics

\begin{tabular}{|l|c|c|c|c|c|c|}
\hline Variable & $\mathrm{N}$ & mean & $\mathrm{p} 50$ & $\mathrm{sd}$ & skewness & kurtosis \\
\hline Conformity & 3404 & 1.741 & 1.793 & 0.387 & -0.251 & 4.247 \\
\hline differentiation & 3404 & 0.178 & 0.116 & 0.197 & 3.154 & 15.74 \\
\hline research_input & 3404 & 3.589 & 2.890 & 4.557 & 4.588 & 37.53 \\
\hline research_staff & 3404 & 9.480 & 4.735 & 13.13 & 2.242 & 9.095 \\
\hline tobinQ & 3404 & 1.946 & 1.517 & 1.416 & 5.762 & 72.22 \\
\hline Lev & 3404 & 0.472 & 0.482 & 0.196 & -0.047 & 2.448 \\
\hline
\end{tabular}

\begin{tabular}{|l|c|c|c|c|c|c|}
\hline Indiratio & 3404 & 0.376 & 0.364 & 0.060 & 1.873 & 8.037 \\
\hline Ownership & 3404 & 0.551 & 1 & 0.497 & -0.207 & 1.043 \\
\hline
\end{tabular}

\subsection{Relevance analysis}

To avoid "pseudo-regression", it is necessary to analyze the correlation between the respective variables, as shown in Table 3. It can be seen that $R \& D$ cost investment, $R \& D$ personnel investment, and financial performance are significantly positively correlated, and CSR consistency is significantly negatively correlated with financial performance, only the correlation between CSR variability and financial performance is not significant. To further understand the impact of each variable on financial performance, the following regression model will be developed to explore it in depth.

Table 3. Correlation analysis

\begin{tabular}{|c|c|c|c|c|c|c|c|c|}
\hline & 1 & 2 & 3 & 4 & 5 & 6 & 7 & 8 \\
\hline 1.conformity & 1 & & & & & & & \\
\hline 2.differentiation & $-0.365 * * *$ & 1 & & & & & & \\
\hline 3.research_input & -0.015 & $0.091 * * *$ & 1 & & & & & \\
\hline 4.research_staff & $-0.033 *$ & $0.096 * * *$ & $0.592 * * *$ & 1 & & & & \\
\hline 5.tobinQ & $-0.159 * * *$ & 0.024 & $0.288 * * *$ & $0.201 * * *$ & 1 & & & \\
\hline 6. Lev & $0.029 *$ & $-0.050 * * *$ & $-0.282 * * *$ & $-0.171 * * *$ & $-0.423 * * *$ & 1 & & \\
\hline 7. Indiratio & 0.015 & 0.001 & $0.037 * *$ & $0.033 *$ & 0.016 & $0.055 * * *$ & 1 & \\
\hline 8. Ownership & -0.002 & -0.012 & $-0.223 * * *$ & $-0.169 * * *$ & $-0.180 * * *$ & $0.235 * * *$ & 0.006 & 1 \\
\hline
\end{tabular}

\subsection{Regression analysis}

Table 4. Regression analysis

\begin{tabular}{|c|c|c|c|c|c|c|c|c|}
\hline VARIABLES & $\begin{array}{c}(1) \\
\mathrm{m} 1 \\
\text { tobinQ } \\
\end{array}$ & $\begin{array}{c}(2) \\
\mathrm{m} 2 \\
\text { tobinQ } \\
\end{array}$ & $\begin{array}{c}(3) \\
\text { m3 } \\
\text { tobinQ } \\
\end{array}$ & $\begin{array}{c}(4) \\
\mathrm{m} 4 \\
\text { tobinQ }\end{array}$ & $\begin{array}{c}(5) \\
\text { m5 } \\
\text { tobinQ } \\
\end{array}$ & $\begin{array}{c}(6) \\
\text { m6 } \\
\text { tobinQ } \\
\end{array}$ & $\begin{array}{c}(7) \\
\mathrm{m} 7 \\
\text { tobinQ } \\
\end{array}$ & $\begin{array}{c}(8) \\
\text { m8 } \\
\text { tobinQ } \\
\end{array}$ \\
\hline L.research_input & & & $\begin{array}{c}-0.212^{* * *} \\
(-4.50)\end{array}$ & $\begin{array}{c}-0.748^{* * *} \\
(-6.07)\end{array}$ & $\begin{array}{l}0.101 \\
(0.33)\end{array}$ & & & \\
\hline L.research_staff & & & & & & $\begin{array}{c}-0.226^{* * *} \\
(-11.65)\end{array}$ & $\begin{array}{c}-0.819 * * * \\
(-6.84)\end{array}$ & $\begin{array}{l}-0.255 \\
(-0.94)\end{array}$ \\
\hline L.conformity & $\begin{array}{c}1.032 * * * \\
(16.80)\end{array}$ & $\begin{array}{c}2.584 * * * \\
(5.31)\end{array}$ & $\begin{array}{c}1.007 * * * \\
(16.41)\end{array}$ & $\begin{array}{c}0.999 * * * \\
(16.43)\end{array}$ & $\begin{array}{c}2.545^{* * *} * \\
(5.18)\end{array}$ & $\begin{array}{c}0.678 * * * \\
(10.18)\end{array}$ & $\begin{array}{c}0.683 * * * \\
(10.28)\end{array}$ & $\begin{array}{c}2.215^{* * * *} \\
(4.45)\end{array}$ \\
\hline L.conformity ${ }^{2}$ & & $\begin{array}{c}-0.448 * * * \\
(-2.95)\end{array}$ & & & $\begin{array}{c}-0.445 * * * \\
(-2.90)\end{array}$ & & & $\begin{array}{c}-0.441 * * * \\
(-2.82)\end{array}$ \\
\hline L.conformity*research_input & & & & $\begin{array}{c}0.359 * * * \\
(5.46)\end{array}$ & $\begin{array}{c}-0.657^{*} \\
(-1.70)\end{array}$ & & & \\
\hline L.conformity ${ }^{2 *}$ research_input & & & & & $\begin{array}{c}0.326^{* * * *} \\
(2.64)\end{array}$ & & & \\
\hline L.conformity*research_staff & & & & & & & $\begin{array}{c}0.343 * * * \\
(5.11)\end{array}$ & $\begin{array}{l}-0.402 \\
(-1.17)\end{array}$ \\
\hline L.conformity ${ }^{2 *}$ research_staff & & & & & & & & $\begin{array}{c}0.242 * * \\
(2.17)\end{array}$ \\
\hline L.differentiation & $\begin{array}{c}0.854 * * * \\
(7.74)\end{array}$ & $\begin{array}{c}-0.526 * * \\
(-2.16)\end{array}$ & $\begin{array}{c}0.813 * * * \\
(7.39)\end{array}$ & $\begin{array}{c}0.851^{* * *} \\
(7.80)\end{array}$ & $\begin{array}{c}-0.570 * * \\
(-2.36)\end{array}$ & $\begin{array}{c}0.581 * * * \\
(5.33)\end{array}$ & $\begin{array}{c}0.563 * * * \\
(5.19)\end{array}$ & $\begin{array}{c}-0.511 * * \\
(-2.18)\end{array}$ \\
\hline L.differentiation ${ }^{2}$ & & $\begin{array}{c}1.955^{* * *} \\
(6.39)\end{array}$ & & & $\begin{array}{c}1.967 * * * \\
(6.40)\end{array}$ & & & $\begin{array}{c}1.582 * * * \\
(5.31)\end{array}$ \\
\hline L.differentiation*research_input & & & & -0.067 & $-0.569 * *$ & & & \\
\hline
\end{tabular}


L.differentiation ${ }^{2 *}$ research_input

L.differentiation*research_staff

L.differentiation ${ }^{2 *}$ research_staff
$(-0.55)$

$(-2.14)$

0.171

$(0.58)$

\begin{tabular}{ccccc} 
& & & $0.290^{* * *}$ & $0.436^{* *}$ \\
& & & $(2.88)$ & $(2.17)$ \\
& & & & -0.354 \\
0.285 & $0.315^{*}$ & 0.294 & $0.348^{*}$ & $0.350^{*}$ \\
$(1.51)$ & $(1.69)$ & $(1.59)$ & $(1.90)$ & $(1.92)$ \\
-0.071 & 0.020 & 0.170 & 0.184 & 0.256 \\
$(-0.18)$ & $(0.05)$ & $(0.43)$ & $(0.47)$ & $(0.66)$ \\
0.243 & 0.287 & 0.125 & 0.165 & 0.211 \\
$(1.33)$ & $(1.59)$ & $(0.70)$ & $(0.92)$ & $(1.19)$ \\
$-1.953 * * *$ & $-3.216^{* * *}$ & $-1.449 * * *$ & $-1.483 * * *$ & $-2.749 * *$ \\
$(-8.41)$ & $(-7.26)$ & $(-6.28)$ & $(-6.47)$ & $(-6.17)$ \\
2,457 & 2,457 & 2,457 & 2,457 & 2,457 \\
0.170 & 0.194 & 0.201 & 0.213 & 0.227 \\
YES & YES & YES & YES & YES \\
YES & YES & YES & YES & YES \\
\hline
\end{tabular}

el, ** indicates significance at the 0.05 level, and $* * *$ indicates significance at the 0.01 level)

on the relationship between CSR consistency and financial performance $(b=0.359, p<0.01)$. Based on this, model 5 adds the interaction term of the secondary term of the consistency of CSR with the investment in R\&D expenses and the results are significant (coefficients of the interaction terms of the primary and secondary terms are 0.657 and 0.326 , respectively, $p<0.1$ ) and the regression coefficients of the consistency of CSR on financial performance are dissimilar (coefficients of the primary and second terms are 2.545 and -0.445 , respectively), the results suggest that increasing the investment in $R \& D$ expenses weakens the inverted U-shaped relationship between consistency of CSR and financial performance. As can be seen from Fig. 2, the effect on financial performance tends to be linear over the range of values of the consistency of CSR when the investment in R\&D expenses is larger. Therefore, hypothesis H2a partially holds.

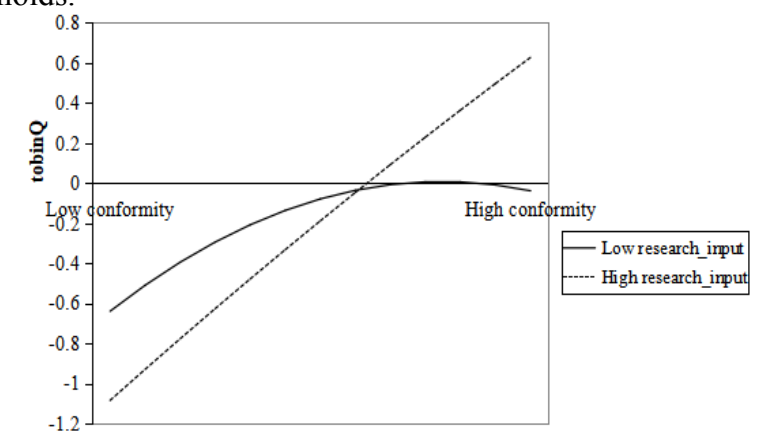

Figure 2. The moderating effect of R\&D expenditure investment on the relationship between consistency and financial performance of CSR

On the other hand, the regression results of model 4 indicate that the moderating effect of $R \& D$ expenditure investment on the relationship between the variability of CSR and financial performance is not significant. Therefore, the results of model 5, which increases the interaction term of the quadratic term of the variability of 
CSR with the investment in R\&D expenses, are also not significant, indicating that increasing the investment in $R \& D$ expenses does not have a moderating effect on the Ushaped relationship between the variability of CSR and financial performance. Therefore, hypothesis $\mathrm{H} 2 \mathrm{~b}$ does not hold.

Models 6-8 first include the interaction term of $R \& D$ personnel input with different dimensions of social responsibility for the moderating effect, and model 6 is statistically significant $(\mathrm{R} 2=0.201, \mathrm{p}<0.01)$ mainly for testing the independent variables and moderation. The regression results of model 7 indicated a significant positive moderating effect of R\&D cost personnel input on the relationship between CSR consistency and financial performance $(b=0.343, p<0.01)$. Based on this, model 8 adds the interaction term of the quadratic term of the consistency of CSR with R\&D personnel input, and the results are significant (coefficients of the interaction terms of the primary and secondary terms are -0.402 and 0.242 , respectively, $\mathrm{p}<0.05$ ) and the regression coefficients of the consistency of CSR on financial performance are heteroscedastic (coefficients of the primary and secondary terms are 2.215 and -0.441 , respectively). The results indicate that increasing the investment in R\&D personnel weakens the inverted U-shaped relationship between the consistency of CSR and financial performance. As can be seen from Fig. 3, the effect on financial performance tends to be linear over the range of values of the consistency of CSR when the investment in R\&D personnel is larger. Therefore, hypothesis $\mathrm{H} 2 \mathrm{a}$ holds.

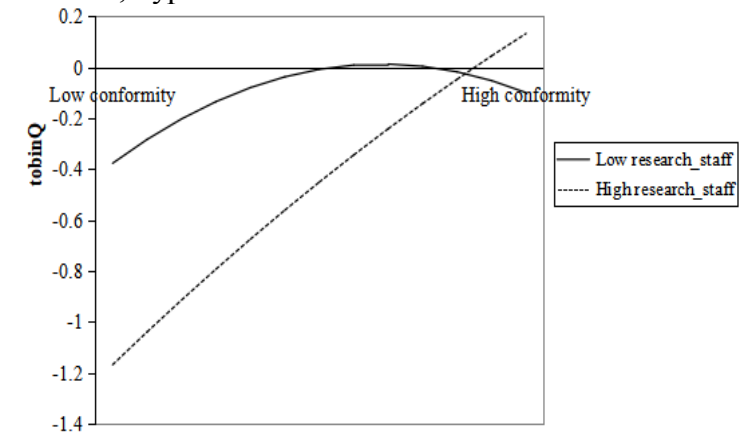

Figure 3. The moderating effect of R\&D expenditure investment on the relationship between consistency and financial performance of CSR

On the other hand, the regression results of model 7 indicate a significantly positive moderating effect of R\&D personnel input on the relationship between variability in CSR and financial performance $(b=0.290, p<0.01)$. Based on this, model 8 adds the interaction term of the quadratic term of the variability of CSR with the R\&D personnel input, which is not significant, and the results indicate that increasing the input of personnel cost has no moderating effect on the U-shaped relationship between the variability of CSR and financial performance. Therefore, hypothesis H2b does not hold.

\subsection{Robustness tests}

To ensure the robustness of the results, this paper does a robustness test, this paper uses (total assets - net intangible assets - net goodwill), instead of total assets to calculate the value of tobinQ, the regression results are still consistent.

\section{CONCLUSION}

Through theoretical analysis and empirical testing, this paper draws the following research conclusions:

(1) The fulfillment of social responsibility by enterprises in China started late, and there are differences between different enterprises, and there is still a certain gap with the average level of developed countries. However, it is undeniable that the number of voluntary disclosures of social responsibility reports by listed companies has gradually increased each year, and enterprises have become aware of the need to assume social responsibility, pay more attention to the value of concern and contribution to the surrounding social environment in the production process, and make the maximization of auxiliary profits as the second goal of enterprises.

(2) The relationship between corporate social responsibility and corporate financial performance is not purely linear. This result proves that the competitive advantage brought by the consistent behavior of CSR will not last long without a unique and non-replicable CSR strategy, thus negatively affecting the financial performance of the company. The differentiation of CSR is not easily recognized by the public upfront, leading to a decrease in financial performance; however, it is accumulated over time, allowing the company to establish a new competitive advantage with differentiation, which leads to a financial performance that can be improved.

(3) Overall, corporate R\&D investment may lead to a decrease in corporate financial performance in a short period, but in the long run, the accumulated financial performance will eventually be transformed into unique core competitiveness of the enterprise, and stakeholders should be confident in the future development of the enterprise, and thus financial performance will continue to improve. Through empirical evidence, this paper argues that when companies tend to CSR consistent behavior in the long term, increasing investment in $R \& D$ changes the tendency of the company's financial performance, which originally did not form unique competitiveness and resulted in lower financial performance, into an increase in the company's financial performance and attracts more stakeholders' support and investment, thus continuously improving the company's financial performance. Thus, increasing R\&D investment can weaken the inverted Ushaped effect of CSR's consistent behavior on financial performance. When firms tend to differential behavior of CSR in the long run, increasing investment in R\&D will not change the negative impression that firms leave to stakeholders by neglecting CSR consistency, making it difficult to obtain external resources and thus failing to 
improve financial performance. Therefore, increasing investment in $\mathrm{R} \& \mathrm{D}$ does not have a moderating effect on the U-shaped relationship between CSR's differential behavior and financial performance.

\section{ACKNOWLEDGMENT}

This paper is supported by the National Social Science Foundation of China: "Research on the Impact of HumanMachine Cooperative Behaviour Characteristics on Enterprise Human Resource Management System in the Era of Artificial Intelligence" (NSSFC: 19BGL123).

\section{REFERENCES}

[1]Tim Rowley, Shawn Berman. A Brand New Brand of Corporate Social Performance[J]. Business \& Society, 2000, 39(4):397-418.

[2]Clyde Eiríkur Hull, Sandra Rothenberg. firm Performance: The Interactions of Corporate Social Performance with Innovation and Industry Differentiation[J]. Strategic Management Journal, 2008, 29(7):781-789.

[3]Herman Aguinis. What We Know and Don't Know About Corporate Social Responsibility [J]. Journal of Management, 2012, 38(4):932-968.

[4]Flammer Caroline. corporate social responsibility and shareholder reaction: the environmental awareness of investors $[\mathrm{J}]$. The Academy of Management Journal, 2013, 56(3): 758-81.

[5]Archie B. Carroll. A Three-Dimensional Conceptual Model of Corporate Performance [J]. The Academy of Management Review, 1979, 4(4):497-505.

[6]Yanlong Zhang, Heli Wang, Xiaoyu Zhou. Dare to Be Different? Conformity vs. Differentiation in Corporate Social Activities of Chinese Firms and Market Responses[J]. Academy of Management Journal, 2017.
[7]Hannah Sean T., Sayari Naz, Harris Frederick H. deB., Cain Carol L.. The Direct and Moderating Effects of Endogenous Corporate Social Responsibility on Firm Valuation: Theoretical and Empirical Evidence from the Global Financial Crisis[J]. Journal of Management Studies, 2020, 58(2).

[8]Michael L. Barnett, Robert M. Salomon. does it pay to be really good? addressing the shape of the relationship between social and financial performance[J]. Strategic Management Journal, 2012, 33(11).

[9]Zhang ZG, Jin SC, Li GQ. An empirical study on the interactive intertemporal impact between corporate social responsibility and financial performance $[\mathrm{J}]$. Accounting Research, 2013, (08):32-39+96. (In Chinese).

[10]Hillebrand B, Driessen P H, Koll O.Stakeholder marketing: Theoretical foundations and required capabilities[J]. Journal of the Academy of Marketing Science, 2015, 43(4):411-428.

[11]Amrou Awaysheh, Randall A. Heron, Tod Perry, Jared I. Wilson. on the relation between corporate social responsibility and financial performance $[\mathrm{J}]$. Strategic Management Journal, 2020, 41(6).

[12]Pushpika Vishwanathan, Hans (J.) van Oosterhout, Pursey P. M. A. R. Heugens, Patricio Duran, Marc Essen. Strategic CSR: A Concept Building Meta Analysis[J]. Journal of Management Studies, 2020, 57(2):

[13]Xueming Luo, C.B. Bhattacharya. The Debate over Doing Good: Corporate Social Performance, Strategic Marketing Levers, and Firm-Idiosyncratic Risk[J]. Journal of Marketing, 2009, 73(6).

[14]Li, Mengya, Yan, Taihua. Venture capital, financial performance and firm performance: The influence mechanism and its empirical test $[\mathrm{J}]$. Scientific Research Management, 2020, 41(07):70-78. (In Chinese). 